\title{
Door de bril van de beklaagde
}

\section{Wie is dat en wat mag hij van ons als klachtbehandelaars verwachten?}

\author{
Natalia Molina Espeleta
}

\begin{abstract}
In dit artikel neemt Natalia Molina Espeleta u mee in de belevingswereld van de beklaagde en staat zij stil bij de vraag wat de beklaagde - zowel juridisch gezien als uit oogpunt van behoorlijkheid - van ons als klachtbehandelaars mag verwachten.
\end{abstract}

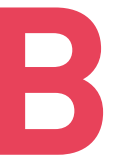

urgerperspectief. Door de bril van de burger kijken. Het is een van de belangrijkste uitgangspunten van klachtbehandeling. Als onderzoeker bij de Nationale ombudsman is het zelfs de kern van mijn dagelijks werk. Onze missie luidt immers niet voor niets 'wij geloven dat het perspectief van burgers geborgd moet worden in alles wat de overheid doet'. Het is ook een eenzijdig perspectief. Want achter menig klacht gaat niet alleen een burger schuil met zijn ervaring, emoties, hoop en verwachtingen, maar ook een persoon op wiens gedraging de klacht betrekking heeft: de beklaagde medewerker.

\section{Wie is de beklaagde?}

Volgens titel 9 van de Algemene wet bestuursrecht (Awb) gaan klachten over gedragingen van bestuursorganen. De gedraging van een medewerker van dat bestuursorgaan (hierna: instantie) wordt volgens artikel 9:1, tweede lid, van de Awb, aangemerkt als een gedraging van het bestuursorgaan zelf. Op die manier is duidelijk wie in juridische zin wordt beoordeeld en verantwoordelijk wordt geacht.

Tegelijk is dit natuurlijk een illusie. Ja, er zijn klachten die echt op gedragingen van instanties zien. Slechte telefonische bereikbaarheid van een instantie als geheel is bijvoorbeeld niet aan één medewerker toe te rekenen. Een niet gering aantal klachten ziet echter op wat er in het contact tussen een burger en een medewerker van die instantie gebeurt. Of die medewerker nu zelf beslist hoe hij zich in dat contact gedraagt, of dit hem is opgelegd, de burger klaagt over wat er tussen hem en medewerker $X$ is voorgevallen. De medewerker is degene op wiens gedraging de klacht betrekking heeft. De medewerker is beklaagde.

\section{Wat ervaart de beklaagde?}

Als we het woord beklaagde opzoeken in de Van Dale dan staat er 'beschuldigde'. Dat is nogal een heftige term. Maar het is ook heftig, zo'n klacht over jouw handelen. De afgelopen jaren sprak ik in mijn werk met tientallen beklaagden. En hoewel ik soms twijfel of dat wel het woord is dat we moeten gebruiken om deze mensen aan te duiden, doet het tegelijkertijd recht aan hun positie en gevoelens. Slechts een klein deel van de beklaagde medewerkers die ik sprak, trok zich de klacht niét persoonlijk aan. Bij de anderen hoorde ik twijfel (heb ik het nu wel goed gedaan?), angst (wat gaat deze klacht voor mij betekenen?), woede (ik heb echt álles voor deze burger uit de kast getrokken en nu dit) en onmacht lgaat iemand die er het fijne niet van weet hier nu een oordeel over geven?). 


\section{beklaagde}

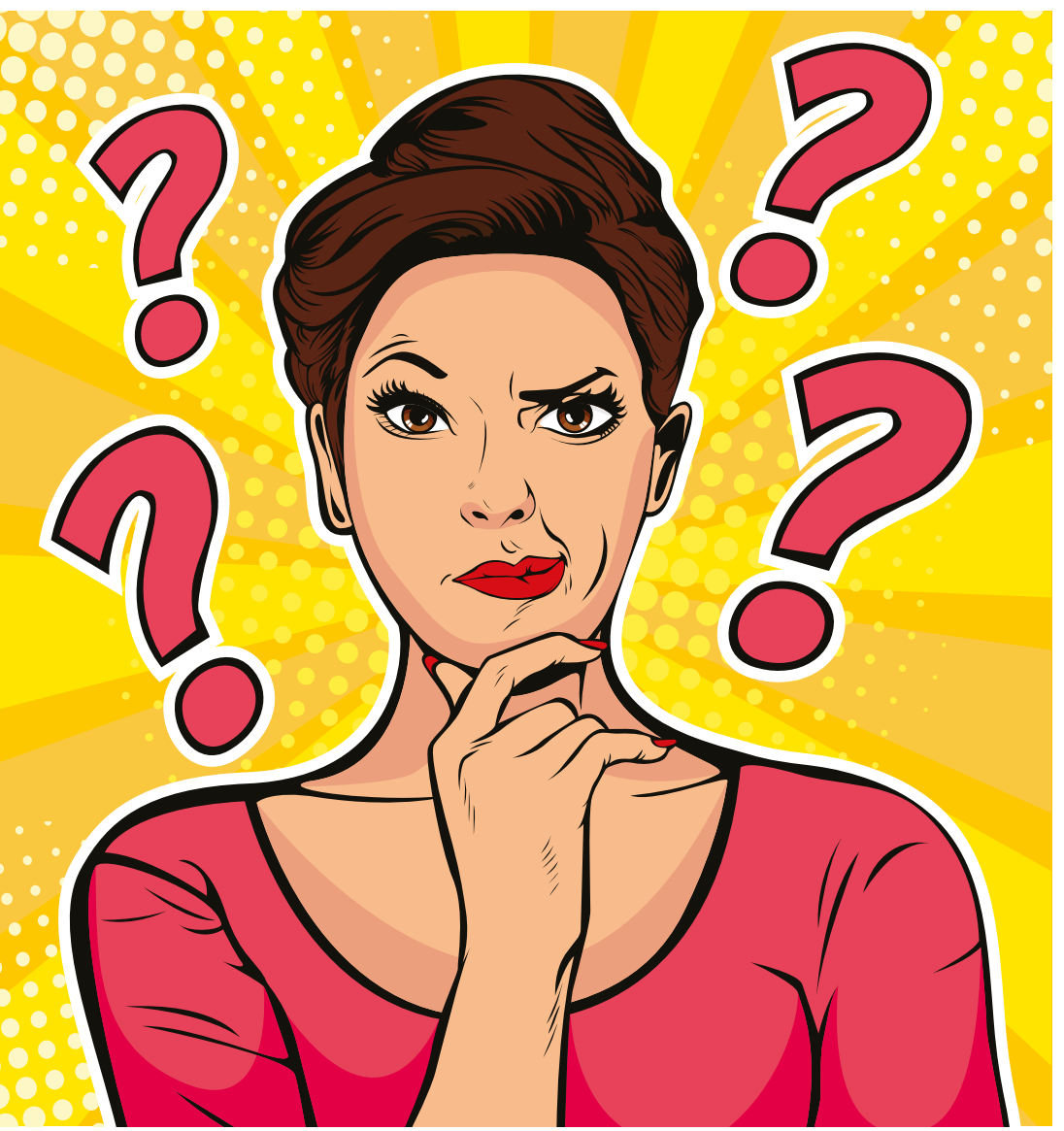

En deze gevoelens hoorde ik niet alleen bij anderen. Ook ikzelf ervaarde soortgelijke emoties toen burgers klachten over mij en mijn werk indienden. Zelfs in een klachtvriendelijke omgeving als de ombudsman, waar elke klacht als een kans wordt gezien, voelde ik ongemak en onzekerheid toen er een klacht over mij werd ingediend. Moet je nagaan hoe dat is als je niet bekend bent met het klachtrecht en niet weet hoe binnen jouw organisatie naar klachten wordt gekeken. Of wat als het nog een tandje erger is, en jouw organisatie klachten helemaal niet ziet als kansen of leermomenten, maar toch echt als iets wat zoveel mogelijk moet worden vermeden?

\section{Genoeg aandacht voor de beklaagde?}

Mijn eigen ervaringen als beklaagde wakkerden opnieuw een vraag aan die vaker in mijn achterhoofd knaagt: hebben we als klachtbehandelaars wel genoeg aandacht voor de beklaagde?

Het deed me allereerst denken aan de ambtenaren die wij als ombudsman in het kader van onze onderzoeken horen. Je zou denken dat niemand daarop zit te wachten: de hele interne klachtbehandeling doorlopen, klacht ongegrond, en dan nog eens een nieuwe ronde bij de ombudsman. En hoewel dat gevoel natuurlijk vaak ook aanwezig is, horen we net zo regelmatig 'wat fijn dat jullie de tijd nemen om van mij te horen wat er is gebeurd.' Het deed me ook denken aan die keer dat ik in het kader van een onderzoek op locatie op uitnodiging van een beklaagde ging kijken hoe een bepaald proces in de praktijk werkte. Hoe moeizaam het bezoek verliep, en hoe tijdens het gesprek aan het eind van dat bezoek bij haar de tranen naar boven kwamen. Want dit was niet even zakelijk uitleggen hoe een bepaald proces in de praktijk werkte. Dit was je wéér moeten verdedigen, maar nu tegenover de ombudsman, in die klacht die toch allang afgehandeld was.

En het deed me tot slot denken aan die keer dat een klachtbehandelaar mij op de studiemiddag bij de Vereniging voor Klachtrecht vertelde beklaagden nooit te informeren over de uitkomst van klachtbehandeling, want waarom zou je dat nu doen?

\section{Rechten van de beklaagde}

Los van het feit dat het misschien gewoon wel zo behoorlijk is degene die bij de klacht betrokken was te informeren over de uitkomst daarvan, is het goed om allereerst stil te staan bij het feit dat de beklaagde op grond van de Awb bepaalde rechten heeft. Daarin wordt weliswaar niet expliciet het recht genoemd om geïnformeerd te worden over de uitkomst van de interne klachtbehandeling door het bestuursorgaan zelf. Toch biedt de Awb daar wel aanknopingspunten toe. Op grond van artikel 9:11 van de Awb wordt de beklaagde namelijk wel geïnformeerd over het verdagen van de afhandeling van de klacht. Hetgeen mijns inziens impliceert dat de wetgever ervan uitgaat dat de beklaagde belang heeft bij het volgen van de klachtprocedure en de uitkomst daarvan.

En dat is niet het enige wat uit de Awb kan worden afgeleid over de rechten van de beklaagde. Kort samengevat heeft de beklaagde in ieder geval expliciet het recht om:

- geïnformeerd te worden over de klacht (art. 9:9 en 9:30, eerste lid);

- gehoord te worden over de klacht lart. 9:10, eerste lid en 9:30, eerste lid);

- geïnformeerd te worden over het staken van het onderzoek door een ombudsman lart. 9:25, tweede (id);

- de bevindingen van een ombudsman te ontvangen en daarop te reageren (art. 9:35);

- het oordeel van een ombudsman te ontvangen (9:36, derde lid). 


\section{Behoorlijke behandeling van de beklaagde}

Klachtbehandeling draait niet alleen om de Awb en om wat iemands rechten zijn. Klachtbehandeling gaat juist ook over wat behoorlijk is. Dat geldt net zo goed bij de beantwoording van de vraag wat een beklaagde in klachtbehandeling mag verwachten.

In het najaar van 2020 deed ik samen met een aantal collega's een design sprint rondom dit vraagstuk. 'We bouwden een testwebsite voor beklaagden, die we vervolgens daadwerkelijk met ambtenaren testen. Zo kregen we nog helderder in beeld waar beklaagden zelf behoefte aan hebben. Uit de design sprint bleek dat met name de behoorlijkheidsvereisten van transparantie, goede informatieverstrekking en luisteren naar de burger (die medewerker is óók gewoon een burger, een persoon) van groot belang zijn om ervoor te zorgen dat klachtbehandeling ook door de beklaagde als professionele en behoorlijke klachtbehandeling wordt ervaren.

De behoorlijkheidsvereisten en de overige feedback van deze design sprint tezamen genomen, kom ik tot de conclusie dat we als klachtbehandelaars een verantwoordelijkheid hebben om in ieder geval de volgende acties te ondernemen:

- Informeer de medewerker over het feit dat de klacht is ingediend.

- Normaliseer: geef uitleg over klachtbehandeling. Vertel iets over hoe logisch het is dat er in het contact tussen overheid en burger klachten kunnen ontstaan, hoe veelvoorkomend die klachten binnen de eigen organisatie zijn en hoe daarnaar gekeken wordt, dat klachten juist ook een kans zijn om te leren en dat het daar in de klachtbehandeling om draait. Normaliseren kan uiteraard ook al vóórdat iemand beklaagde is, door binnen de organisatie aandacht te besteden aan de rol die klachten spelen in het interne leerproces.

- Verduidelijk proces en rollen. Bij wie kan de medewerker terecht voor informatie, bij wie voor steun en wie geeft het oordeel? Hoe ziet het proces eruit, wat zijn eventuele gevolgen van een oordeel (en wat juist niet) en wat zijn mogelijke vervolgstappen?

- Heb oog voor de medewerker. Zorg dat de medewerker zich gehoord voelt. Heb daarbij aandacht voor diens gevoelens en emoties. Ga niet alleen af op schriftelijke informatie bij de beoordeling van een klacht, maar ga bij de medewerker na of je goed hebt begrepen wat er is gebeurd én waarom dat is gebeurd. Juist ook bij gevoelige onderwerpen kan het fijn zijn voor de medewerker om zijn verhaal kwijt te kunnen. ${ }^{2}$

- Hecht goed af: reflecteer samen op de klacht, het oordeel en de klachtbehandeling, óók als de klacht ongegrond is.

- Betrek de medewerker bij het leren van de klacht. Juist de medewerker weet vaak waarom dingen in de dagelijkse praktijk op een bepaalde manier gaan. En kan dus ook meedenken over wat er nodig is om dat in de toekomst anders te doen. Sommige medewerkers staan er ook voor open hun ervaringen breder met de organisatie te delen. Zo kan een individueel inzicht een organisatie-inzicht worden.

\section{Samen verder}

Als u als lezer van dit artikel iets bijblijft, dan hoop ik dat dat vooral is dat klachtbehandeling niet alleen een proces is tussen burger en overheidsinstantie, maar ook tussen beklaagde medewerker en overheidsinstantie. In dit artikel heb ik een aantal concrete handvatten voor u als klachtbehandelaar geschetst. Het is van belang daarbij op te merken dat oog hebben voor de positie van de beklaagde niet alleen vanuit de klachtbehandelaar moet komen. Er is hierin uiteraard ook een rol weggelegd voor de leidinggevende en de lcultuur binnen de) organisatie als geheel. Mogelijk dat dit artikel voor u - net als voor mij - dan ook de aanzet kan zijn om het gesprek hierover zowel binnen als buiten uw organisatie aan te gaan of verder te brengen. Want alleen samen komen we verder.

Wilt u reageren op dit artikel, verder praten over de positie van de beklaagde of uw eigen ervaringen als klachtbehandelaar of beklaagde delen? Neem dan contact op via n.molinalanationaleombudsman.nl.

\section{Noten}

1 Een design sprint is een methode om design thinking in een kort tijdsbestek praktisch te maken. Doel daarbij is om van uitdaging naar oplossing te gaan en feedback op te halen bij de gebruiker. Het perspectief van de gebruiker speelt op deze manier een centrale rol bij het ontwerpen en ontwikkelen van dienstverlening. Zie voor meer informatie www.designsprint.gebruikercentraal.nl.

2 Zie ook rapport 2021/030 van de Nationale ombudsman, Verkleurde beelden, hoe moet de overheid omgaan met klachten over etnisch profileren?, par. 8.4.

Mr. N.T. Molina Espeleta is redactielid van dit tijdschrift. Zij schrijft dit artikel op persoonlijke titel. 